\title{
Water disinfection using acoustic cavitation: A mini review
}

\author{
Maharshi Yadav ${ }^{*}$, Jyoti ${ }^{1}$, Vitthal L. Gole ${ }^{1}$ \\ ${ }^{1 *}$ Department of Chemical Engineering, Madan Mohan Malaviya University of Technology, Gorakhpur, INDIA \\ "Corresponding Author: e-mail: maharshiyadav@outlook.com, Tel +91-8375858788
}

\begin{abstract}
The waterborne disease is a major concern for India and root cause of this non-ability of water disinfection technology at affordable cost to all. Hence it is necessary to understand the disinfection of water to achieve goal of healthy society. Various methods and technologies like Chlorination, iodine, silver, coagulation flocculation, iron Nano particles, UV, Solar disinfection, distillation, Reverse osmosis, slow sand filters, activated charcoal filter, electrochemical oxidation, cavitation, plasma techniques, electrocoagulation, photo catalysis and many more have been evolved over the years. Despite of availability of techniques for water disinfection, but larger scale application still is a major challenge, especially in developing countries where almost eighty percent diseases are cause by waterborne. Acoustic cavitation is base technique highly useful for water disinfection. This mini review discussed various aspects of acoustic cavitation and potential application for water disinfection. Acoustic cavitation with chemical disinfection techniques is also very beneficial because it reduces the use of chemical so production of byproducts reduces automatically.
\end{abstract}

Keywords:Disinfection, Cavitation, Acoustic Cavitation, waterborne diseases.

DOI: http://dx.doi.org/10.4314/ijest.v13i1.10S

Cite this article as:

Yadav M., Jyoti, Gole V.L. 2021. Water disinfection using acoustic cavitation: A mini review, International Journal of Engineering, Science and Technology, Vol. 13, No. 1, pp. 69-75. doi: 10.4314/ijest.v13i1.10S

Received: December 1, 2019; Accepted: February 5, 2021; Final acceptance in revised form: March 31, 2021

This paper was earlier presented at the International Conference on Energy, Environment \& Material Sciences (ICE2M), 1-3 December 2019 and substantially improved for this Special Issue. Guest Editor: Dr. Sri Niwas Singh, Professor (HAG), Department of Electrical Engineering, Indian Institute of Technology Kanpur, 208016 (U.P.) India, former Vice-Chancellor, Madan Mohan Malviya University of Technology Gorakhpur (April 2017 to July 2020).

\section{Introduction}

Water is integral component of millions of living bodies, daily need of humans and other species. Purity of water is major concern for the human society to achieve the healthy society and sustainability goals. Over the years of scientific and technological advancement has developed various physical, chemical, and biological techniques to purify the water. Commonly practice techniques for water disinfection are gravity settling, coagulation, filtration, and chemical processes like chlorination and ozonation. Chlorination is most commonly and widely used process for water disinfection. Chlorine has mutagenic effects on human body, may leads to cancer and other problems with chlorination are odour and taste. Alternative for chlorine are ozone, silver, copper, ferrate, iodine, bromine, hydrogen peroxide, potassium permanganate. These chemicals are useful for water disinfection with some associated advantages and disadvantages. Physio-chemical systems, such as photo-catalysis, photodynamic, electrochemical and some physical systems, ultraviolet irradiation, pulsed electric fields magnetic and microwave systems are also use for disinfection (Carpenter et al., 2017). For disinfection of water and wastewater we need such phenomenon were risk of 
associated phenomenon should be very low. Cavitation and other advanced oxidation processes are evolving with minimum associated risk compare to chemical processes.

\section{Cavitation}

\subsection{Basics of Cavitation}

Cavitation is a process of formation and collapse number of cavities at million locations in reactor/system. Bubbles formed during cavitation attains very high temperature and pressure (inside bubble) and release of very high energy in extremely small location. Generation of high temperature spots, highly active radicals and turbulence makes cavitation a very efficient and effective method for water disinfection (Gogate, 2007). Cavities can be generated by various methods like acoustic cavitation, hydrodynamic cavitation, optic and particle cavitation. Out of these methods hydrodynamic and acoustic cavitation is well-established techniques at laboratory and pilot scale. Temperature, static pressure, fluid flow dynamics, velocity of fluid is important parameters which affect the formation of cavitating conditions. Temperature can be reached up to $4500 \square \mathrm{C}$ and pressure is about $10000 \mathrm{~atm}$. During the collapsing of cavities it leads to formation of high oxidizing power chemical species $\mathrm{HO} \square, \mathrm{HO}_{2^{-}}$, which have potential to remove organic pollutant from water. Cavitation have nowadays use in various fields like in producing emulsion solution, for making highly efficient heating devices, different types of surfaces cleaning, it is very useful in pumping of highly viscous fluid, effluent treatment, organic contaminant treatment, cosmetic treatment etc. Chemical synthesis, cell disruption in biotechnology, sono-crystallization. Atomization (process of formation of small droplets) obtained by cavitation technology. This mini review addressed the concerns of water and water disinfection aspects of cavitation using acoustic and hydrodynamic cavitation and associated microbial aspects.

\subsection{Types of cavitation \& Cavitational Reactors;}

Cavitation is classified base on formation of the cavitation bubbles and following four ways are useful for understanding.

1.Hydrodynamic cavitation

2.Vaporous cavitation

3. Gaseous cavitation

4.Acoustic cavitation

Gogate et al (2006) classified cavitation in four types such as hydrodynamic cavitation, acoustic cavitation, optic cavitation and fourth particle cavitation. Optic cavitation generated by very high intensity of photon particles (laser beam)(Gogate et al., 2001; Gogate \& Pandit, 2000) rapturing it in liquid medium, particle cavitation is generated by elementary particles (neutron) beam rapturing a liquid. Two types of cavitational reactors are most common in use first sonochemical reactors and another is hydrodynamic cavitational reactor. Important configurations of sonochemical reactors are given below-

1.Ultrasonic horn and bath

2.Dual frequency flow cell

3.Triple frequency fuel cell

4.Ultrasonic bath with longitudinal vibrations

Ultrasound can be generated by various gas and liquid driven transducers, electromechanical transducers like magnetostrictive and piezoelectric. Ultrasonic bath, probe and the ultrasonic flow cell are commonly used sonication equipment (L. Zhang et al., 2017).

Gogate and Kabaddi (2009) describes details of hydrodynamic cavitation, according to them hydrodynamic cavitation generated by the high RPM of any object in liquid medium. Hydrodynamic devices such as high-speed homogenizer, high-pressure homogenizer, and speed rotor are able to generate cavitational conditions but due high energy, cost investment for these reactors make it non-feasible for the water treatment purposes. Comparing the intensity of collapsing of cavity hydrodynamic cavitation produce less intensity but in term of the cavity generation hydrodynamic cavitation have advantage because of its geometrical configurations(Destaillats et al., 2001).

Mahulkar and Pandit (2010) described two possible way of cavity collapsing one is symmetrical collapsing and another is asymmetrical collapsing. Symmetrical collapsing stated for those collapsing in which bubble maintain spherical or distorted spherical shape till the point of collapse, production of free radicals and thermal pyrolysis occurs in efficiently. Further collapsing of the bubble takes place in a symmetrical or asymmetrical way and depends upon the nearby cavities(Save et al., 1997). Collapsing cavity generate extremely intense shock waves. Asymmetrical collapsing is favorable for microbes killing and symmetrical collapsing is favorable for production of high oxidation potential radicals such $\mathrm{HO} \square, \mathrm{HO} 2-$ and $\mathrm{H} 2 \mathrm{O} 2$ due to decomposition of water molecules (Gogate et al., 2006). Shock wave generated due to collapsing of cavity cause shock wave of $550 \mathrm{MPa}$ at speed of approximately $2000 \mathrm{~m} / \mathrm{s}$ and water jets (micro water jets from during asymmetrical collapsing) generate a kind water hammer effect of $450 \mathrm{MPa}$ at $100 \mathrm{~m} / \mathrm{s}$. Thermal effect is plays very important role, at collapsing cavity hot spot of $2000 \mathrm{~K}$ $5000 \mathrm{~K}$ is generated its persuades the heat transfer of $1010 \mathrm{~K} / \mathrm{s}$. Thermal, chemical and physical effects provide killing of water microbes and degradation of water pollutant (Ferrari, 2017).

Cavitation is classified in 4 category and these categories are depends upon the way cavity is generated, hydrodynamic cavitation, acoustic cavitation, optic cavitation, and particle cavitation. Out of four cavitation hydrodynamic cavitation and acoustic cavitation is more suitable for water and wastewater treatment. Hydrodynamic cavitation is more energy efficient and more scope of developing at commercial scale for water and wastewater treatment. 


\section{Acoustic Cavitation}

Ultrasound has many applications, but one of the most important is cell disruption of bacteria, viruses, animal cells fungal cell etc. It is proved that limited quantity of bacteria cells can be disintegrated very efficiently using ultrasound. Transient and stable acoustic cavitation are two forms of ultrasonic cavitation violent collapsing of bubbles occurs in transient way and microstreaming occurs in stable cavitation.

\subsection{Factors affecting the Acoustic cavitation:}

Frequency and intensity of sound wave is most important of acoustic cavitation and other parameters are liquid medium properties such as viscosity and surface tension. Increase in frequency leads to decrease in cavitation due to very small rarefaction period (Gągol et al., 2018; Yadav et al., 2020). Increasing the viscosity of medium up to optimum level increase the cavitation. Temperature, presence of dissolved gases helps to increase the cavitation. Increasing the sound wave intensity provides more cavitation and these are useful parameters cell disruption studies of bacteria. Increase in size of microbial cell decrease the cell rapturing because bigger cell can withstand larger tensile stress (Li et al., 2014).

\subsection{Mechanism of microbial inactivation:}

Conclusive mechanism for cell disruption is still not established but following key points plays role in cell disruption.

3.2.1Mechanical Effects:Doulah and Hammond (1975) proposed the eddies formation by sound waves results to the pressure difference across the cell wall of microbes and if pressure difference sufficient enough and cross cell wall strength disintegration of microbes occurs(Mahvi, 2009).

3.2.2 Shear Stress:localized shear stress developed during the transient cavitation due to formation of shock waves, these shock waves produce sufficient shear stress and turbulence to rapture the cell wall.

3.2.3 Free Radical Formation and Dis-agglomeration: Sonntag (1996) observed that not only physical forces but free radical generation because of cavitation are also responsible for the microbes killing (Moholkar \& Pandit, 2001).

articles in professional journals, which publishes papers for specialists and do not ordinarily pay for contributions, may benefit a person in many ways. Such publications are likely to increase career advancement, to increase your circle of your professional acquaintances, to get feedback of your ideas, etc. Usually, papers submitted to the journals are very large and many a times they are either rejected or returned with a request for major/ minor revisions. A paper is turned down for a number of reasons, which is not only due to the quality of work but also due to the quality of presentation. Although quality of work and presentation are equally important.

\section{Acoustic Cavitation as Water Disinfection}

Microbial cell destruction using ultrasound waves are started early in 1920s by work of Loomis and Harvey. Scherba et al. examine various fungus, bacteria and viruses on ultrasound of $26 \mathrm{kHz}$ and find that at high intensity and high exposure time bacteria killing occurs (Vajnhandl et al., 2015). Mason et al. used martin Walter push and pull reactor at $27 \mathrm{kHz}$ for water disinfection, after $60 \mathrm{~min}$ of sonication approximately $73 \%$ of viable bacteria destroyed. Similar unit of ultrasonic used for cooling tower water treatment at flow rate of $10 \mathrm{l} / \mathrm{min}$ and sonication unit was of $300 \mathrm{~W}$ for 120 hours, $85 \%$ of viable bacteria deactivated (Mason et al., 2003). Jyoti and Pandit used bore well water for bacterial deactivation analysis using ultrasonic alone and combinations with ozone(Jyoti \& Pandit, 2004). Researcher studied microbial deactivation analysis on four bacteria/group of bacteria and find almost $99 \%$ removal using ultrasonic bath and ozone $(0.5 \mathrm{mg} / \mathrm{l})$.Almost same results obtained for ultrasonic horn and ozone combination, using alone ultrasonic horn and ultrasonic bath achieved 50\% to 57\% percentage disinfection (Jyoti \& Pandit, 2004). This studied proves that use of chemical disinfectant can be reduce by assisting disinfection process with ultrasonication. Dadijour et al. studied ultra-sonication with $\mathrm{TiO} 2$ and called it sonocatalytic disinfection(Dadjour et al., 2005) on E.coli. Culture were studied in absence of $\mathrm{TiO} 2$ and also in presence, $2 \%$ reduction found in 30 min period using only ultrasonic, with $1.0 \mathrm{~g} / \mathrm{ml}$ concentration of $\mathrm{TiO} 2$ with ultrasonic achieved $13 \%$ bacterial reduction which indicated significant growth in bacterial reduction. Tsukamoto et el. 2003 investigated inactivation of yeast cells at $27.5 \mathrm{mHz}$, researcher consider yeast cells similar to Cryptosporidium parvum which is very resistant to germicides because of hard oocysts(Tsukamoto et al., 2004). Using horn type sonicator at $27.5 \mathrm{MHz}$ at $33 \mathrm{ml} / \mathrm{min}$ flow rate up to $97 \%$ inactivation achieved while at higher flow of $1500 \mathrm{ml} / \mathrm{min}$ inactivation decreases to $79 \%$. This study indicates that water disinfection can be achieved even if water includes Cryptosporidium parvum like persistent microorganism.

Futura et al. 2004 studied water disinfection using horn type sonicator $(27.5 \mathrm{kHz})$ utilizing the squeeze-film effect and measured the formation of hydrogen peroxide during irradiation by using KI colorimetric method. Using this squeeze-film type system, more than $99 \%$ of E. coli cells was inactivated within 180-s sonication at the amplitude of $3 \mathrm{~lm}(\mathrm{p}-\mathrm{p})$ and $2 \mathrm{~mm}$ of the thickness of the squeeze film. Study also confirmed that more than $99 \%$ of the Saccharomyces cerevisiae cells were inactivated after 40 seconds of Ultrasonic irradiation at $7 \mu \mathrm{m}(\mathrm{p}-\mathrm{p})$ and $2 \mathrm{~mm}$ of the thickness of the squeeze film and almost $80 \%$ of the Cryptosporidium parvum oocytes were morphologically damaged after 300-s treatment at the amplitude of $4 \mu \mathrm{m}$ (Furuta et al., 2004).

Zhang et al. studied the removal of Microcystis aeruginosa using ultrasound for 5 minutes at $50 \mathrm{~W}$ decrease significantly color of algae solution(Zhang et al., 2006). K. Iqbal et al. studied the effect of high-intensity focused ultrasound (HIFU) on Enterococcus faecalis on both planktonic suspensions and biofilms and concluded that HIFU causes bactericidal effects. Ortuno (2014) studies inactivation kinetics of Escherichia coli (E. coli) and Saccharomyces cerevisiae (S. cerevisiae) cells in apple juice subjected to 
supercritical carbon dioxide (SC-CO $\mathrm{CO}_{2}$ ) assisted by high power ultrasound (HPU) at different pressures (100-350 bar, $\left.36^{\circ} \mathrm{C}\right)$ and temperatures $\left(31-41^{\circ} \mathrm{C}, 225 \mathrm{bar}\right)$ and concluded that shorter process time required to achieve total inactivation. There was a direct relationship observed between cellular modification/damage and inactivation provoked by the $\mathrm{SC}-\mathrm{CO}_{2}$ and $\mathrm{SC}-\mathrm{CO}+\mathrm{HPU}$ treatments on E. coli and S. cerevisiae cells(Ortuño et al., 2014).

Gao et al. 2014 used high frequency ultrasound $850 \mathrm{kHz}$ to kill Enterobacter aerogenes, Bacillus subtilis and Staphylococcus epidermidis as well as a yeast in controlled temperature, 99\% inactivation of bacteria achieved. ultrasound generator K80 (Meinhardt Ultraschalltechnik, Germany) at $850 \mathrm{kHz}$, which was connected to an ultrasonic transducer E/805/T and a doublewalled cylindrical glass vessel. Researcher concluded that the longer the residence time of the bacteria in the ultrasonicated medium, that is after sonication treatment is stopped, the higher the number of inactivated bacteria cells(Gao et al., 2014).Ultrasonic Resonator was developed Osman et al. for the Ballast water disinfection named it as multiple-orifice resonators (MOR)(Osman et al., 2016), researcher demonstrated that use of multiple orifice plates increases the ultrasonic irradiation surface two times without any increase in mass of device. MOR resonators can potentially increase efficiency of disinfection. Using Bacteriophages MS2 (E. coli (ATTC 15597-B1)) and ФX174 (Host bacterium is E.coli (ATCC 13706)) obtained 0.123 per minute inactivation rate at $582 \mathrm{kHz}+$ visible light combination For MS2 (initial concentration is $11,133 \mathrm{pfu} / \mathrm{ml}$ ). Using combination of ultrasonic $(582 \mathrm{kHz})$ and visible light bacteria phase $\Phi$ X174 (initial concentration $6388 \mathrm{pfu} / \mathrm{ml}$ ) received inactivation rate of 0.042 per minute, researcher concluded that MS2 inactivation is faster comparing to $\Phi$ X174 and the combined use of US and VL should be employed only on specific cases(Chrysikopoulos et al., 2013). Antoniadis et al. examined the sonication of municipal wastewater and observed that high power(Antoniadis et al., 2007) and low frequency combination is eliminating complete E.coli. Onder et al. studied combination of ultrasound, chlorine dioxide and provided that using sequential combination is more promising comparing to using alone(Ayyildiz et al., 2011).

Table 1. Water Disinfection Using Acoustic Cavitation

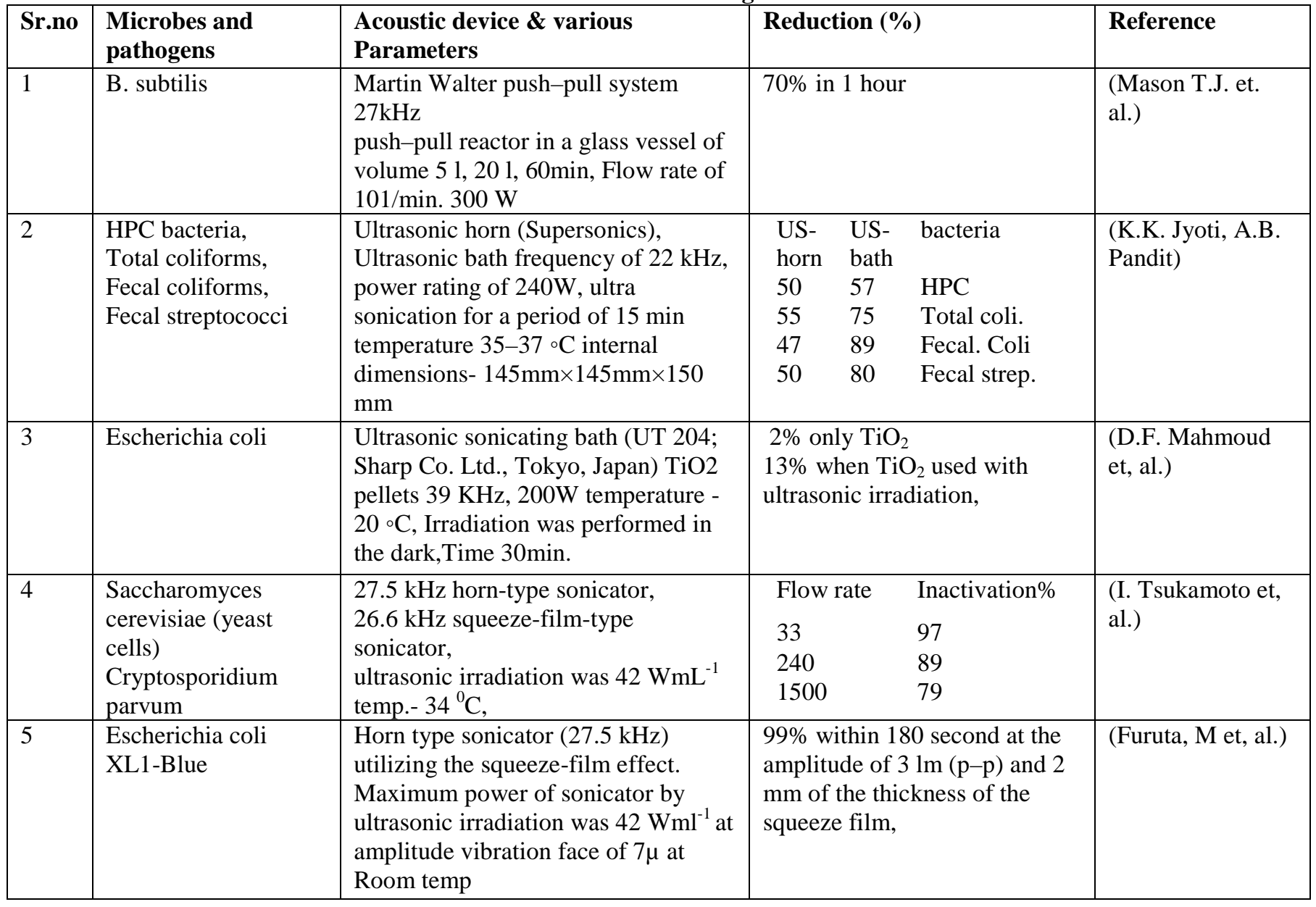


Table 2 (Cont'd). Water Disinfection Using Acoustic Cavitation

\begin{tabular}{|c|c|c|c|c|}
\hline Sr.no & $\begin{array}{l}\text { Microbes and } \\
\text { pathogens }\end{array}$ & $\begin{array}{l}\text { Acoustic device \& various } \\
\text { Parameters }\end{array}$ & Reduction (\%) & Reference \\
\hline 6 & $\begin{array}{l}\text { Microcystis } \\
\text { aeruginosa }\end{array}$ & $\begin{array}{l}20 \text { and } 80 \mathrm{kHz} \text { ultrasound waves, } \\
\text { generates } 150,410,690,1320 \mathrm{kHz} \\
\text { ultrasound waves. Working volume } \\
\text { of the cell system- } 1000 \mathrm{~mL} \text { Surface } \\
\text { area- } 15.3 \mathrm{~cm} 2 . \text { Temperature } \\
\text { controlled at } 25 \pm 3^{0} \mathrm{C} \text {, }\end{array}$ & $\begin{array}{l}\text { Chlorophyll a concentration } \\
\text { change to } 0.26 \mathrm{mg} / \mathrm{l} \text { after } 20 \\
\text { minutes sonication, } 80 \mathrm{kHz}, 80 \\
\text { W }\end{array}$ & $\begin{array}{l}\text { (Z, Guangming et, } \\
\text { al.) }\end{array}$ \\
\hline 7 & Enterococcus faecalis & $\begin{array}{l}\text { High-intensity focused ultrasound } \\
\text { (HIFU), bowl-shaped, } 64-\mathrm{mm}- \\
\text { diameter piezo-ceramic transducer, } \\
\text { resonance frequency of } 250 \mathrm{kHz} \text {, } \\
\text { water tank with dimensions of } \\
15 \times 15 \times 25 \mathrm{~cm}^{3} \text { HIFU source } \\
\text { transducer- geometrical focus and } \\
\text { focal depth of the transducer were } \\
59.97 \mathrm{~mm} \text { and } 50.65 \mathrm{~mm} \text {, } \\
\text { The strongest ultrasonic pressure } \\
(\sim 10 \text { bar }) \text { is measured at the focus }\end{array}$ & $\begin{array}{l}\text { No viable cells were detected } \\
\text { after } 60 \text { or } 120 \mathrm{~s} \text { of exposure to } \\
\text { HIFU in planktonic } \\
\text { suspensions, }\end{array}$ & (Kulsum et al.) \\
\hline 8 & $\begin{array}{l}\text { Escherichia coli (E. } \\
\text { coli) and } \\
\text { Saccharomyces } \\
\text { cerevisiae (S. } \\
\text { cerevisiae) cells }\end{array}$ & $\begin{array}{l}\text { High power ultrasound (HPU) } \\
\text { different pressures }(100-350 \mathrm{bar}, 36 \\
\left.{ }^{\circ} \mathrm{C}\right) \\
\text { temperatures }\left(31-41{ }^{\circ} \mathrm{C}, 225 \mathrm{bar}\right) \\
\text { Power generator unit }(40 \mathrm{~W} \pm 5 \mathrm{~W}) \text {. } \\
\text { resonance frequency of } 30 \mathrm{kHz}\end{array}$ & $\begin{array}{l}\text { E. coli cells-After the first } \\
\text { minute, the population } \\
\text { decreased slowly and on } \\
\text { average, a reduction of } 7.5 \mathrm{log} \text { - } \\
\text { cycles was obtained after } 7 \mathrm{~min} \\
\text { S. cerevisiae- The population } \\
\text { reductions obtained after } 1 \mathrm{~min} \\
\text { of treatment were } 1.8,3.9 \text { and } \\
4.8 \text { log-cycles, at } 31,36 \text { and } 41 \\
{ }^{\circ} \mathrm{C} \text {, respectively. }\end{array}$ & $\begin{array}{l}\text { (Carmen Ortuno, } \\
\text { et. al.) }\end{array}$ \\
\hline 9 & $\begin{array}{l}\text { E. aerogenes, B. } \\
\text { subtilis, S. } \\
\text { epidermidis, and A. } \\
\text { pullulans }\end{array}$ & $\begin{array}{l}\text { Ultrasound generator K80 } \\
\text { (Meinhardt Ultra schalltechnik, } \\
\text { Germany) at } 850 \mathrm{kHz} \text {, Ultrasonic } \\
\text { transducer E/805/T Glass vessel was } \\
\text { filled with } 250 \mathrm{ml} \text { Milli-Q water. } 5 \\
\text { ml microbial suspensions were } \\
\text { transferred into a } 15 \mathrm{ml} \text { glass tube } \\
\text { Working temperature in the vessel } 20 \\
{ }^{0} \mathrm{C} \text {. }\end{array}$ & $\begin{array}{l}\sim 4.2, \sim 2.5 \text { and } \sim 4.4 \log \\
\text { reductions achieved at } 62 \mathrm{~W} \\
\text { for } 20 \text { min Ultrasonication for } \\
\text { E. aerogenes, B. subtilis and } \mathrm{S} \text {. } \\
\text { epidermidis, respectively, in } \\
\text { stationary phase. }\end{array}$ & $\begin{array}{l}\text { (Shengpu Gao et } \\
\text { al.) }\end{array}$ \\
\hline 10 & $\begin{array}{l}\text { Bacteriophages } \\
\text { MS2(E. coli (ATTC } \\
\text { 15597-B1)) and } \\
\text { ФX174 (Host } \\
\text { bacterium is E.coli } \\
\text { (ATCC 13706)) }\end{array}$ & $\begin{array}{l}\text { (Meinhardt Ultra- schalltechnik, with } \\
75 \mathrm{~mm} \text { titanium transducer, function } \\
\text { generator and amplifier. } \\
\text { 2L glass reactor, operating Frequency } \\
582,862 \text {, and } 1142 \mathrm{kHz} \\
\text { Visible light } \\
\text { combined US + VL }\end{array}$ & $\begin{array}{l}\text { MS2 inactivation faster than } \\
\Phi X 174, \\
\Phi X 174-\text { At } C_{0} \text { of } 6388 \mathrm{pfu} / \mathrm{ml} \\
\text { and } 582 \mathrm{kHz} \text { inactivation } \\
\text { coefficient is } 0.0421 / \mathrm{m} \text {, } \\
\text { MS2 - At C of } 11133 \mathrm{pfu} / \mathrm{ml} \text { at } \\
582 \mathrm{kHz} \text { inactivation } \\
\text { coefficient is } 0.1231 / \mathrm{m} \text {, }\end{array}$ & $\begin{array}{l}\text { (Chrysikopoulos } \\
\text { et al.) }\end{array}$ \\
\hline
\end{tabular}


Table 3 (Cont'd). Water Disinfection Using Acoustic Cavitation

\begin{tabular}{|c|c|c|c|c|}
\hline Sr.no & $\begin{array}{l}\text { Microbes and } \\
\text { pathogens }\end{array}$ & $\begin{array}{l}\text { Acoustic device \& various } \\
\text { Parameters }\end{array}$ & Reduction (\%) & Reference \\
\hline 11 & E.coli. & $\begin{array}{l}\text { 1- Ultrason } 250 \text { (LabPlant, UK) } \\
\text { ultrasound generator, } \\
80 \mathrm{kHz}, 150 \mathrm{~W} \text {, horn of } 7 \mathrm{~mm} \text { tip } \\
\text { 2- } 24 \mathrm{kHz}, \text { a UP } 400 \mathrm{~S} \text { (Dr Hielscher } \\
\text { GmbH, Germany) horn-type } \\
\text { sonicator, } \\
\text { 100ml sample used for irradiation. }\end{array}$ & $\begin{array}{l}\text { Microbial loading reduced to } \\
5000 \mathrm{col} / \mathrm{ml} \text { from } 10^{6} \mathrm{col} / \mathrm{ml}\end{array}$ & (Antoniadis et al.) \\
\hline 12 & $\begin{array}{l}\text { E.coli., Total } \\
\text { Coliform }\end{array}$ & $\begin{array}{l}\text { Ultrasonic generator (Vibra Cell505, } \\
500 \mathrm{~W} \text { and } 20 \mathrm{kHz} \text {, metallic probe of } \\
1.9 \mathrm{~cm} \text { dia. }\end{array}$ & $\begin{array}{l}\text { For the power range of } 75-300 \\
\text { W/L, doubling ultrasonic } \\
\text { power } \\
\text { enhanced E. coli and TC log } \\
\text { inactivation by a factor of } 1.7- \\
2.8\end{array}$ & (Onder et al) \\
\hline
\end{tabular}

Various researchers find acoustic cavitation a very efficient tool for water disinfection; acoustic cavitation becomes more useful when used with other chemical disinfectant. At the lab scale acoustic cavitation is very effective but for the larger scale of water disinfection it's still challenging task for the researchers. For every technologies cost is one of the most important factor, many technologies available efficiently but there actual application with economical cost is still bigger challenge than research itself. Cost of ultrasonic horn used alone for water disinfection is much higher than using ozone/hydrogen peroxide for same degree of disinfection. Nevertheless, cost get reduce when ultrasonic horn used with ozone, but it is still higher than using ozone alone for same disinfection. Compare to ultrasonic horn ultrasonic bath have comparatively less cost per liter for achieving same disinfection(Kishen Kumar \& Pandit, 2012). Using acoustic cavitation with chemical disinfectant reduces the amount the chemical requires which also leads to the reduction in harmful by products formation.

\section{Conclusions}

Cavitation is emerging water disinfection technology and since last decade research is continuing cavitation base technologies. Nowadays, researches on more focused on effect of acoustic cavitation on E.coli. Extensive research done on water disinfection using acoustic cavitation but making acoustic cavitation feasible for large scale and economical for domestic scale. Several water treatment units based on cavitation patented overs last few years like DYNAJETS, VRTX, HyCa, Vorsana Radial Counter flow reactor etc. Future contains promising believe in cavitational technology for water treatment. Combining acoustic cavitation and hydrodynamic cavitation with other technologies are now bigger field of research.

\section{References}

Antoniadis, A., Poulios, I., Nikolakaki, E., \& Mantzavinos, D. (2007). Sonochemical disinfection of municipal wastewater. Journal of Hazardous Materials, 146(3), 492-495. https://doi.org/10.1016/j.jhazmat.2007.04.065

Ayyildiz, O., Sanik, S., \& Ileri, B. (2011). Effect of ultrasonic pretreatment on chlorine dioxide disinfection efficiency. Ultrasonics Sonochemistry, 18(2), 683-688. https://doi.org/10.1016/j.ultsonch.2010.08.008

Carpenter, J., Badve, M., Rajoriya, S., George, S., Saharan, V. K., \& Pandit, A. B. (2017). Hydrodynamic cavitation: An emerging technology for the intensification of various chemical and physical processes in a chemical process industry. Reviews in Chemical Engineering, 33(5), 433-468. https://doi.org/10.1515/revce-2016-0032

Chrysikopoulos, C. V., Manariotis, I. D., \& Syngouna, V. I. (2013). Virus inactivation by high frequency ultrasound in combination with visible light. Colloids and Surfaces B: Biointerfaces. https://doi.org/10.1016/j.colsurfb.2013.01.038

Dadjour, M. F., Ogino, C., Matsumura, S., \& Shimizu, N. (2005). Kinetics of disinfection of Escherichia coli by catalytic ultrasonic irradiation with TiO2. Biochemical Engineering Journal, 25(3), 243-248. https://doi.org/10.1016/j.bej.2005.04.028

Destaillats, H., Lesko, T. M., Knowlton, M., Wallace, H., \& Hoffmann, M. R. (2001). Scale-up of sonochemical reactors for water treatment. Industrial and Engineering Chemistry Research, 40(18), 3855-3860. https://doi.org/10.1021/ie010110u

Ferrari, A. (2017). Fluid dynamics of acoustic and hydrodynamic cavitation in hydraulic power systems. Proceedings of the Royal Society A: Mathematical, Physical and Engineering Sciences, 473(2199). https://doi.org/10.1098/rspa.2016.0345

Furuta, M., Yamaguchi, M., Tsukamoto, T., Yim, B., Stavarache, C. E., Hasiba, K., \& Maeda, Y. (2004). Inactivation of Escherichia coli by ultrasonic irradiation. Ultrasonics Sonochemistry, 11(2), 57-60. https://doi.org/10.1016/S13504177(03)00136-6 
Gągol, M., Przyjazny, A., \& Boczkaj, G. (2018). Wastewater treatment by means of advanced oxidation processes based on cavitation - A review. Chemical Engineering Journal, 338(November 2017), 599-627. https://doi.org/10.1016/j.cej.2018.01.049

Gao, S., Hemar, Y., Ashokkumar, M., Paturel, S., \& Lewis, G. D. (2014). Inactivation of bacteria and yeast using high-frequency ultrasound treatment. Water Research, 60, 93-104. https://doi.org/10.1016/j.watres.2014.04.038

Gogate, P. R. (2007). Application of cavitational reactors for water disinfection: Current status and path forward. Journal of Environmental Management, 85(4), 801-815. https://doi.org/10.1016/j.jenvman.2007.07.001

Gogate, P. R., \& Pandit, A. B. (2000). Engineering design methods for cavitation reactors II: Hydrodynamic cavitation. AIChE Journal, 46(8), 1641-1649. https://doi.org/10.1002/aic.690460815

Gogate, P. R., Shirgaonkar, I. Z., Sivakumar, M., Senthilkumar, P., Vichare, N. P., \& Pandit, A. B. (2001). Cavitation reactors: Efficiency assessment using a model reaction. AIChE Journal, 47(11), 2526-2538. https://doi.org/10.1002/aic.690471115

Gogate, P. R., Tayal, R. K., \& Pandit, A. B. (2006). Cavitation: A technology on the horizon. Current Science, 91(1), 35-46.

Jyoti, K. K., \& Pandit, A. B. (2004). Ozone and cavitation for water disinfection. Biochemical Engineering Journal, 18(1), 9-19. https://doi.org/10.1016/S1369-703X(03)00116-5

Kishen Kumar, J., \& Pandit, A. B. (2012). Drinking water disinfection techniques. In Drinking Water Disinfection Techniques. https://doi.org/10.1201/b13705

Li, P., Song, Y., \& Yu, S. (2014). Removal of Microcystis aeruginosa using hydrodynamic cavitation: Performance and mechanisms. Water Research, 62, 241-248. https://doi.org/10.1016/j.watres.2014.05.052

Mahvi, A. H. (2009). Application of ultrasonic technology for water and wastewater treatment. Iranian Journal of Public Health, $38(2), 1-17$.

Mason, T. J., Joyce, E., Phull, S. S., \& Lorimer, J. P. (2003). Potential uses of ultrasound in the biological decontamination of water q. 10, 319-323. https://doi.org/10.1016/S1350-4177(03)00102-0

Moholkar, V. S., \& Pandit, A. B. (2001). Modeling of hydrodynamic cavitation reactors: A unified approach. Chemical Engineering Science, 56(21-22), 6295-6302. https://doi.org/10.1016/S0009-2509(01)00253-6

Ortuño, C., Quiles, A., \& Benedito, J. (2014). Inactivation kinetics and cell morphology of E. coli and S. cerevisiae treated with ultrasound-assisted supercritical CO2. Food Research International, 62, 955-964. https://doi.org/10.1016/j.foodres.2014.05.012

Osman, H., Lim, F., Lucas, M., \& Balasubramaniam, P. (2016). Development of an Ultrasonic Resonator for Ballast Water Disinfection. Physics Procedia, 87(April 2015), 99-104. https://doi.org/10.1016/j.phpro.2016.12.016

Save, S. S., Pandit, A. B., \& Joshi, J. B. (1997). Use of Hydrodynamic Cavitation for Large Scale Microbial Cell Disruption. Food and Bioproducts Processing, 75(1), 41-49. https://doi.org/10.1205/096030897531351

Tsukamoto, I., Yim, B., Stavarache, C. E., Furuta, M., Hashiba, K., \& Maeda, Y. (2004). Inactivation of Saccharomyces cerevisiae by ultrasonic irradiation. Ultrasonics Sonochemistry, 11(2), 61-65. https://doi.org/10.1016/S1350-4177(03)00135-4

Vajnhandl, S., Željko, T., Majcen Le Marechal, A., \& Valh, J. V. (2015). Feasibility study of ultrasound as water disinfection technology. Desalination and Water Treatment, 55(5), 1393-1399. https://doi.org/10.1080/19443994.2014.927331

Yadav, M., Gole, V. L., \& Jyoti. (2020). Microbial inactivation of groundwater using ultrasound and chemical additives ( H 2 O 2 and $\mathrm{TiO} 2$ ). Journal of Indian Chemical Society, 97(10), 1-4.

Zhang, G., Zhang, P., Wang, B., \& Liu, H. (2006). Ultrasonic frequency effects on the removal of Microcystis aeruginosa. Ultrasonics Sonochemistry, 13(5), 446-450. https://doi.org/10.1016/j.ultsonch.2005.09.012

Zhang, L., Qi, H., Yan, Z., Gu, Y., Sun, W., \& Zewde, A. A. (2017). Sonophotocatalytic inactivation of E. coli using ZnO nanofluids and its mechanism. Ultrasonics Sonochemistry, 34, 232-238. https://doi.org/10.1016/j.ultsonch.2016.05.045

\section{Biographical notes}

Maharshi Yadav; Received M. Tech. in Environmental Engineering fromMMMUT, Gorakhpur India in 2018and Pursuing PhD in Chemical Engineering from MMMUT respectively. His main area of research is Environmental flow assessment, Noise pollution, Environmental monitoring and assessment, Water disinfection and treatment.

Dr. Jyoti; isAssistant Professor in the Department of Chemical Engineering, MMMUT, Gorakhpur India. she has more than 12 years of experience in teaching and research. Her main area of research are Advanced oxidation Processes, Polymeric composites, Water treatment.

Dr. Vitthal L. Gole: is Associate professor and Head in the Department of Chemical Engineering, MMMUT, Gorakhpur India. He has more than 17 years of teaching and research experience. His main area of research areProcess Intensification, Sonochemistry, Advanced Oxidation Process. 